\title{
Allele-Specific PCR Assay to Genotype SNP rs7903146 in TCF7L2 Gene for Rapid Screening of Diabetes Susceptibility
}

\section{perspectives}

\author{
Ludmila Alves Sanches Dutra \\ Patrícia Godoy Garcia Costa \\ Lara Franciele Ribeiro Velasco \\ Angélica AMorim AMATo \\ Gustavo Barcelos BarRa
}

Sabin Institute and Sabin Laboratory of Clinical Analysis (LASD, PGGC, LFRV, GBB); Section

of Endocrinology, University Hospital of Brasilia, Faculty of Medicine, University of Brasilia UnB (AAA); Brasilia, DF, Brazil.

Received in $13 / 8 / 2008$

Accepted in 12/9/2008
Objective: The aim of the present study is to validate a rapid and simple allelespecific PCR that genotypes TCF7/L2 rs7903146 (C/T) polymorphism with standard PCR instruments. Methods: Two forward primers with variations in their 3 ' nucleotides were designed in such a way that each was specific for one of the two variants. They were combined with a common reverse primer into two PCR reactions. Specific amplification indicates the presence of the allele. One hundred and four DNA samples were genotyped by this method. To evaluate the assay, the polymorphism spanning region of 63 DNA samples representing the three possible genotypes was sequenced. Results: The rs7903146 allele assignments derived from the allele-specific PCR were in complete agreement with sequencing. Conclusions: The assay described here is a suitable strategy for the TCF7/L2 rs7903146 (C/T) genotyping also allowing rapid and reliable identification. (Arq Bras Endocrinol Metab 2008; 52/8:1362-1366)

Keywords: Type 2 diabetes; TCF7/L2; SNP; rs7903146

\section{RESUMO}

Ensaio de PCR Alelo-Específico para Genotipar o SNP rs7903146 no Gene TCF7L2 para Rápida Triagem de Suscetibilidade ao Diabetes.

Objetivo: $O$ objetivo deste estudo foi validar um método de PCR alelo-específico, rápido e simples, para genotipagem do polimorfismo rs7903146 (C/T) no gene TCF7/L2 utilizando equipamentos convencionais. Métodos: Dois primers forward com variações nos seus nucleotídeos $3^{\prime}$ foram desenhados de forma que cada um fosse específico para uma das variantes. Eles foram combinados com um primer reverso comum em duas reações de PCR. A amplificação de tamanho específico indica a presença do alelo. Cento e quatro amostras de DNA foram genotipadas por esse método. Para validar o ensaio, uma amostragem representativa dos três possíveis genótipos (63 amostras) teve a região contendo o polimorfismo seqüenciada. Resultados: A genotipagem do polimorfismo rs7903146 derivada da PCR alelo-específica estava em completa concordância com o sequenciamento. Conclusões: $O$ ensaio aqui descrito é uma estratégia adequada para a genotipagem do polimorfismo rs7903146 (C/T) do gene TCF7/L2 e permite identificação alélica rápida e precisa. (Arq Bras Endocrinol Metab 2008; 52//8:1362-1366)

Descritores: Diabetes tipo 2; TCF7/L2; SNP; rs7903146

\section{INTRODUCTION}

he prevalence of type 2 diabetes (T2D) is increasing in an alarming rate. Population ageing and obesity are considered the main causes of this "diabetes epidemic", although the risk of developing the disease is also strongly influenced by inheritance. Genetic susceptibility to T2D is believed to be poly- 
genic, but only genetic variants with small effect sizes had been indentified until transcription factor-7-like 2 (TCF7/L2) was identified as the most important T2D susceptibility gene to date (1-3).

Genetic variants in the gene encoding this transcription factor have been consistently associated with T2D and impaired insulin secretion (1, 4-7). Among them, the rs7903146 $\mathrm{T}$ allele is probably the best marker to evaluate the effect of this gene on T2D risk. This allele increases the risk of T2D by 1.45 in heterozygous and by 2.41 in homozygous (5). All these findings have been replicated in populations of different ethnic descent including caucasian Europeans (3), Japanese and Indian people (8-10), Latin Americans (11) and West Africans (12), representing the main ethnical groups with a high prevalence of T2D (2).

The $\mathrm{T}$ allele at rs7903146 also predicted the progression from impaired glucose tolerance to T2D among the participants of the Diabetes Prevention Program (1). Additionally, the T allele has been associated with increased glycosylated hemoglobin levels in both T2D and healthy individuals and among diabetic patients, was present in a higher frequency in those requiring insulin therapy, and underrepresented in those managed by diet alone (13). In addition, it has been shown that the $\mathrm{T}$ allele influences initial treatment response to sulfonylurea therapy, with more treatment failure rates in the TT homozygotes. The heterozygote group displayed an intermediate failure rate and no significant effect of genotype was observed on the response to metformin (14). Furthermore, the rs7903146 also showed a significant association with high triglycerides in families with familial combined hyperlipidaemia (15), and an association with colorectal tumors has also been recently reported $(16,17)$.

TCF7/L2 gene encodes for a transcription factor involved in the canonical beta-catenin-dependent Wnt signaling a pathway, which regulates cell survival, migration, proliferation, differentiation and in organ development (18). Heterodimerization of TCF7/L2 with $\beta$-catenin in the nucleus forms a transcriptionaly productive complex to activate the expression of Wnt-signaling target genes, including intestinal proglucagon $(18,19)$. The proglucagon is the precursor of gut-derived insulinotropic hormone glucagon-like peptide (GLP-1) and it has recently been shown that GLP-1 and its synthetic agonist, exendin-4 (Exd4), induce Wnt signaling in rat's pancreatic beta cells, both in primary islet cells and in INS-1 cells (18). The same au- thors also provided indication that active Wnt signaling stimulates the multiplication of beta cells, and that transfection of a dominant-negative TCF7/L2 inhibits both basal and Exd4-stimulated INS-1 cell proliferation, suggesting that reduced TCF7/L2 action could result in diminished beta cell mass. These results offer physiological evidence supporting the genetic epidemiological studies, suggesting an important role of TCF7/L2 in maintaining beta cell's mass and/or function (18).

However, it is not readily apparent how TCF7/L2 variants, in particular the intronic variant rs7903146, might affect TCF7/L2 expression or its protein product function (1). It has been shown that in T2D patients with rs7903146 T allele TCF7/L2 mRNA expression in islets increased 5 -fold, particularly in homozygote TT (20). Nevertheless, the reasons why impairment of TCF7/L2 action inhibits beta cell proliferation and why TCF7/L2 mRNA expression is increased in T2D are poorly understood. Moreover, the findings heretofore suggest that TCF7/L2 genotyping, particularly rs7903146, could have clinical applications in the near future.

The genotyping methods for rs7903146 used in association studies have always involved sophisticated technologies, like primer extension with detection by MALDI-TOF mass spectroscopy using a SEQUENOM® platform $(1,6,7,20)$ and TaqMan ${ }^{\circledR}$ SNP genotyping assays $(4,9,13)$. These methods are fast, but require expensive dedicated instrumentation. Alongside, "for diagnostic analysis and for scientific studies of a large number of patients, fast and economic assays that can be performed with standard PCR instruments are highly desirable" (21). We describe here a rapid and simple allele-specific PCR methodology for rs7903146 $(\mathrm{C} / \mathrm{T})$ genotyping.

\section{SUBJECTS AND METHODS}

We have designed two forward primers with a mismatch in their last 3' nucleotide such a way that each is specific for one of the two variants of the polymorphism. The forward primers also contain a second mismatch at the third nucleotide from the $3^{\prime}$ end to enhance PCR specificity by additionally hindering the extension of the doubly mismatched primer (22). To maintain the GC\%, different mismatches in the third $3^{\prime}$ base forward primers were employed. A common reverse primer, designed downstream of the polymorphic 
site, did not have mismatches. The allele-specific forward primers (rs7903146 C or rs7903146 T) and the reverse primer (rs7903146 R) were combined in two parallel PCR reactions (Primers' sequences and commentary are listed in Table 1). Since mismatches extend at a lower rate, resulting in an amplification delay, the genotype is scored based on differential amplification of the two alleles.

For rs7903146 (C/T) genotyping validation, 104 DNA samples from healthy and anonymous donors were used. The average age of the volunteers was $27.7 \pm 11$ years, and $59.6 \%$ were male. A written informed consent for DNA analysis was obtained from all the subjects and the use of these samples was approved by the local institutional review board. Genomic DNA was prepared from $50 \mu \mathrm{L}$ of whole blood by the Chelex-100 method (23). For each sample, two PCR reactions were run in parallel, one with primers rs7903146 $\mathrm{C}$ and rs7903146 R (PCR C) and a second with primers rs7903146 $\mathrm{T}$ and rs7903146 R (PCR T), each containing IX PCR Buffer with $\left(\mathrm{NH}_{4}\right)_{2} \mathrm{SO}_{4}, 2 \mathrm{mmol} / \mathrm{L}$ $\mathrm{MgCl} 2,1.25 \mathrm{U}$ of Taq DNA Polymerase (Fermentas, Inc.), $200 \mu \mathrm{mol} / \mathrm{L}$ of each deoxynucleotide triphosphate (Fermentas, Inc), 100ng of each primer and 5-20 $\mu \mathrm{L}$ of genomic DNA in a final volume of $50 \mu \mathrm{L}$. Amplification was performed on a PTC-100 thermal cycler $(\mathrm{MJ}$ research, Inc) and the cycling conditions were as follows: initial denaturation for $3 \mathrm{~min}$ at $94^{\circ} \mathrm{C}$; followed by 32 cycles of $1 \mathrm{~min}$ at $94^{\circ} \mathrm{C}, 1 \mathrm{~min}$ at $50^{\circ} \mathrm{C}$, and $1 \mathrm{~min}$ at $72{ }^{\circ} \mathrm{C}$; and final extension for $5 \mathrm{~min}$ at $72{ }^{\circ} \mathrm{C}$. The PCR products were analyzed by electrophoresis on 1.5\% Tris-acetate-EDTA/ethidium bromide agarose gels, visualized under ultraviolet illumination and the presence of a 205-bp band in PCR C or T indicated the presence of the allele. A sample was considered negative for a particular allele when the amplicon was absent. Furthermore, as the DNA starting material for each allele-specific genotyping reaction came from the same DNA sample, one control the other in detecting either a false negative reaction secondary to extraction failure or the presence of an inhibitor. The accuracy of the genotype discrimination was demonstrated by direct sequencing of the PCR product amplified from 63 selected samples using primers rs7903146 seq and rs7903146 R, which span the polymorphic region. PCR products were sequenced in both the sense and antisense orientations, with the use of an automated sequencer (ABI-377, Perkin-Elmer).

\section{RESULTS}

First of all, the 104 volunteers were genotyped by the new method using $5 \mu \mathrm{l}$ of genomic DNA starting material. We observed that $43(41.34 \%)$ volunteers were homozygote CC, 45 (43.27\%) heterozygote CT and 16 (15.39\%) homozygote TT. This genotype distribution is consistent with Hardy-Weinberg equilibrium. Next, the polymorphic spanning region of 63 selected DNA samples of known genotype, 25 homozygotes CC, 24 heterozygotes $\mathrm{CT}$ and 14 homozygotes TT were sequenced, as described in subjects and methods, and $100 \%$ of concordance between the two methods was observed. A representation of the genotyping by allelespecific PCR and sequencing confirmation can be found in Figure 1.

Moreover, to ascertain the assay reproducibility all 63 sequenced samples were re-tested by the allele-specific PCR, and again 100\% concurrence was obtained.

Table 1. Primers for rs7903146 C/T genotyping by allele-specific PCR and sequencing analysis.

\begin{tabular}{lcc} 
Primer & \multicolumn{1}{c}{ Sequence 5'-3'a } & Commentary \\
rs7903146 C & GAACAATTAGAGAGCTAAGCACTTTTAGAAAC & Forward primer specific for allele C detection \\
rs7903146 T & GAACAATTAGAGAGCTAAGCACTTTTAGAGAI & Forward primer specific for allele T detection \\
rs7903146 R & AGATGAAATGTAGCAGTGAAGTGC & Common reverse primer \\
rs7903146 SEQ & GGTAATGCAGATGTGATGAGATCT & Forward primer for amplification of rs7901 146 \\
\hline
\end{tabular}

Primers for rs $7903146 \mathrm{C} / \mathrm{T}$ genotyping by allele-specific PCR and sequencing analysis; aUnderlined bases indicate primers' differences. 


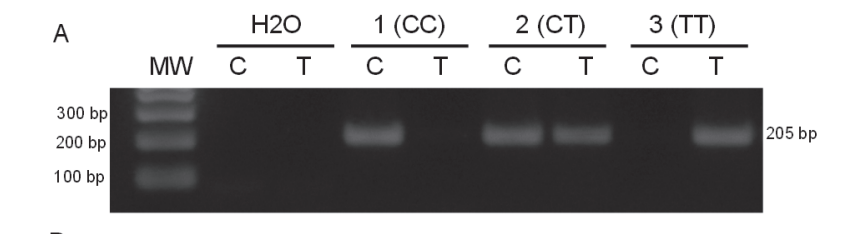

$$
\text { B }
$$
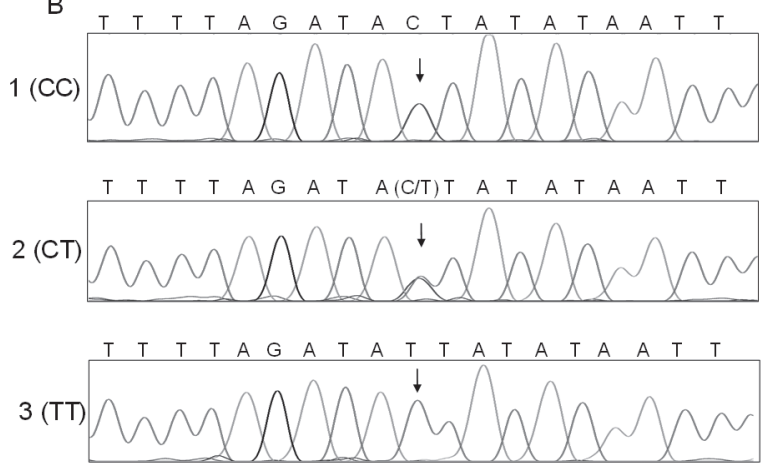

Figure 1. A) Representative genotyping of rs7903146 C/T by allele-specific PCR. For each sample, two PCR reaction were performed, one with primes rs7903146 C and rs7903146 R (PCR C) and a second with primers rs7903146 T and rs7903146 R (PCR T), and run side by side on an agarose gel. A 205-bp band indicated the presence of the allele; amplification failure indicated the absence of the allele. In the gel, the first lane shows the product from the size-standard sample; for the other lanes, $\mathrm{C}$ and $\mathrm{T}$ indicate the product from PCR C and PCR T, respectively, amplified from negative control (water) and from selected DNA sample of each possible genotypes (1 (CC), 2 (CT) and 3 (TT)). B) Sequencing of PCR products amplified with primers rs7903146 SEQ and rs7903146 $R$ from selected DNA sample in A reproducing allele-specific PCR results.

Also, we tested if excess of DNA starting material could harm the allele discrimination. We varied the initial template DNA from 5-20ul and observed that the genotypes were correctly assigned for all tested samples (data not shown).

\section{DISCUSSION}

Our data show that the simple allele-specific PCR method described above is rather effortless and robust, making it suitable for genotyping the polymorphism rs7903146. The basis of the invention is the Amplification Refractory Mutation System (ARMS) method previously described by Newton and colleagues, where oligonucleotides with a mismatched 3'-residue will not function as primers in the PCR under appropriate conditions (22). This genotype system does not require restriction enzyme digestion, sequence analysis of PCR products or the sophisticated genotyping methods used in previous TCF7/L2 association studies. We also observed that the assay performed equally as well with an excess of template starting material. Alongside, we strongly recommend that users optimize the PCR conditions, specially the number of cycles, because genotyping is based on the delay in product amplification and, it is expected, that the excess of cycles could result in poor genotyping discrimination.

The frequencies of the rs7903146 alleles observed in the healthy Brazilian volunteers randomly selected in this study were $63 \%$ for the $\mathrm{C}$ allele and $37 \%$ for $\mathrm{T}$ allele. It was the first genotyping study in the Brazilian population, which represents an heterogeneous ethnic group. The minor allele frequency (T Allele) observed in other populations were: Northern Europeans (18$30 \%$ ), other Caucasians (27-34\%), Asians (3-28\%), and Africans (28-35\%) (4). Moreover, our group will conduct further studies to confirm the association of this single nucleotide polymorphism with T2D in Brazil.

In conclusion, we have determined that the rapid allele-specific PCR method described here is an useful and precise tool for genotyping the SNP rs7903146 in TCF7L2 gene, the strongest T2D susceptibility gene described to date.

Acknowledgments: The authors are greatly indebted to the contribution from Lídia Freire Abdalla, Leonardo Abdala Giacomini, Paula Pires Nascimento, Monalisa Ferreira Azevedo, Dr. Luciana Ansaneli Naves, Janete Ana Ribeiro Vaz, and Sandra Santana Soares Costa. We also gratefully thank the volunteers of the study. Grant/Funding support: This study was supported by Sabin Institute and Laboratory of Clinical Analysis. Financial disclosures: Non applicable. No other conflict of interest relevant to this article was reported.

\section{REFERENCES}

1. Florez JC, Jablonski KA, Bayley N, Pollin TI, de Bakker PI, Shuldiner AR, et al. TCF7L2 polymorphisms and progression to diabetes in the Diabetes Prevention Program. N Engl J Med. 2006;355(3):241-50.

2. Hattersley AT. Prime suspect: the TCF7L2 gene and type 2 diabetes risk. J Clin Invest. 2007;117(8):2077-9.

3. Zeggini E, McCarthy MI. TCF7L2: the biggest story in diabetes genetics since HLA? Diabetologia. 2007;50(1):1-4.

4. Cauchi S, El Achhab Y, Choquet H, Dina C, Krempler F, Weitgasser R, et al. TCF7L2 is reproducibly associated with type 2 diabetes in various ethnic groups: a global meta-analysis. $\mathrm{J}$ Mol Med. 2007.

5. Grant SF, Thorleifsson G, Reynisdottir I, Benediktsson R, Manolescu A, Sainz J, et al. Variant of transcription factor 7-like 2 (TCF7L2) gene confers risk of type 2 diabetes. Nat Genet. 2006;38(3):320-3. 
6. Saxena R, Gianniny L, Burtt NP, Lyssenko V, Giuducci C, Sjogren $\mathrm{M}$, et al. Common single nucleotide polymorphisms in TCF7L2 are reproducibly associated with type 2 diabetes and reduce the insulin response to glucose in nondiabetic individuals. Diabetes. 2006;55(10):2890-5.

7. Scott LJ, Bonnycastle LL, Willer CJ, Sprau AG, Jackson AU, Narisu $\mathrm{N}$, et al. Association of transcription factor 7-like 2 (TCF7L2) variants with type 2 diabetes in a Finnish sample. Diabetes. 2006;55(9):2649-53.

8. Chandak GR, Janipalli CS, Bhaskar S, Kulkarni SR, Mohankrishna P, Hattersley AT, et al. Common variants in the TCF7L2 gene are strongly associated with type 2 diabetes mellitus in the Indian population. Diabetologia. 2007;50(1):63-7.

9. Hayashi T, Iwamoto $Y$, Kaku K, Hirose H, Maeda S. Replication study for the association of TCF7L2 with susceptibility to type 2 diabetes in a Japanese population. Diabetologia. 2007;50 (5):980-4.

10. Horikoshi M, Hara K, Ito C, Nagai R, Froguel P, Kadowaki T. A genetic variation of the transcription factor 7 -like 2 gene is associated with risk of type 2 diabetes in the Japanese population. Diabetologia. 2007;50(4):747-51.

11. Lehman DM, Hunt KJ, Leach RJ, Hamlington J, Arya R, Abboud $\mathrm{HE}$, et al. Haplotypes of transcription factor 7-like 2 (TCF7L2) gene and its upstream region are associated with type 2 diabetes and age of onset in Mexican Americans. Diabetes. 2007;56(2):389-93.

12. Helgason A, Palsson S, Thorleifsson G, Grant SF, Emilsson V, Gunnarsdottir S, et al. Refining the impact of TCF7L2 gene variants on type 2 diabetes and adaptive evolution. Nat Genet. 2007;39(2):218-25.

13. Kimber $\mathrm{CH}$, Doney AS, Pearson ER, McCarthy MI, Hattersley AT, Leese GP, et al. TCF7L2 in the Go-DARTS study: evidence for a gene dose effect on both diabetes susceptibility and control of glucose levels. Diabetologia. 2007;50(6):1186-91.

14. Pearson ER, Donnelly LA, Kimber C, Whitley A, Doney AS, McCarthy $\mathrm{MI}$, et al. Variation in TCF7L2 influences therapeutic response to sulfonylureas: a GoDARTs study. Diabetes. 2007;56 (8):2178-82.

15. Huertas-Vazquez A, Plaisier C, Weissglas-Volkov D, Sinsheimer J, Canizales-Quinteros S, Cruz-Bautista I, et al. TCF7L2 is associated with high serum triacylglycerol and differentially expressed in adipose tissue in families with familial combined hyperlipidaemia. Diabetologia. 2008;51(1):62-9.
16. Folsom AR, Pankow JS, Peacock JM, Bielinski SJ, Heiss G, Boerwinkle E. Variation in TCF7L2 and increased risk of colon cancer: the Atherosclerosis Risk in Communities (ARIC) Study. Diabetes Care. 2008;31(5):905-9.

17. Slattery ML, Folsom AR, Wolff R, Herrick J, Caan BJ, Potter JD. Transcription factor 7-like 2 polymorphism and colon cancer. Cancer Epidemiol Biomarkers Prev. 2008;17(4):978-82.

18. Liu Z, Habener JF. Glucagon-like peptide-1 activation of TCF7L2-dependent Wnt signaling enhances pancreatic betacell proliferation. J Biol Chem. 2008;283:8723-35.

19. Yi F, Brubaker PL, Jin T. TCF-4 mediates cell type-specific regulation of proglucagon gene expression by beta-catenin and glycogen synthase kinase-3beta. J Biol Chem. 2005;280(2):1457-64.

20. Lyssenko V, Lupi R, Marchetti P, Del Guerra S, Orho-Melander $\mathrm{M}$, Almgren $\mathrm{P}$, et al. Mechanisms by which common variants in the TCF7L2 gene increase risk of type 2 diabetes. J Clin Invest. 2007;117(8):2155-63.

21. Endler G, Kyrle PA, Eichinger S, Exner M, Mannhalter C. Multiplexed mutagenically separated PCR: simultaneous single-tube detection of the factor V R506Q (G1691A), the prothrombin G20210A, and the methylenetetrahydrofolate reductase A223V (C677T) variants. Clin Chem. 2001;47(2):333-5.

22. Newton CR, Graham A, Heptinstall LE, Powell SJ, Summers $C$ Kalsheker N, et al. Analysis of any point mutation in DNA. The amplification refractory mutation system (ARMS). Nucleic Acids Res. 1989;17(7):2503-16.

23. Walsh PS, Metzger DA, Higuchi R. Chelex 100 as a medium for simple extraction of DNA for PCR-based typing from forensic material. Biotechniques. 1991;10(4):506-13.

\section{Correspondence to:}

Gustavo Barcelos Barra

Sabin Institute and Sabin Laboratory of Clinical Analysis

SEPS 910 sul Edifício Via Brasil, loja 03, térreo

70390-108 Brasilia, DF

E-mail: gbbarra@gmail.com 